\title{
Fatigue Crack Growth Behavior of Austempered AISI 4140 Steel with Dissolved Hydrogen
}

\author{
Varun Ramasagara Nagarajan ${ }^{1}$, Susil K. Putatunda ${ }^{1, *}$ and James Boileau ${ }^{2}$ \\ 1 Department of Chemical Engineering and Materials Science, Wayne State University, Detroit, MI 48202, USA; \\ varunblr83@yahoo.com \\ 2 Research and Innovation Center, Ford Motor Company, Dearborn, MI 48121, USA; jboileau@ford.com \\ * Correspondence: sputa@eng.wayne.edu, Tel.: +1-313-577-3808
}

Received: 16 August 2017; Accepted: 24 October 2017; Published: 1 November 2017

\begin{abstract}
The focus of this investigation was to examine the influence of dissolved hydrogen on the fatigue crack growth behavior of an austempered low-alloy AISI 4140 steel. The investigation also examined the influence of dissolved hydrogen on the fatigue threshold in this material. The material was tested in two conditions, as-received (cold rolled and annealed) and austempered (austenitized at $882{ }^{\circ} \mathrm{C}$ for $1 \mathrm{~h}$ and austempered at $332{ }^{\circ} \mathrm{C}$ for $1 \mathrm{~h}$ ). The microstructure of the annealed specimens consisted of a mix of ferrite and fine pearlite; the microstructure of the austempered specimens was lower bainite. Tensile and Compact Tension specimens were prepared. To examine the influence of dissolved hydrogen, two subsets of the CT specimens were charged with hydrogen for three different time periods between 150 and $250 \mathrm{~h}$. All of the CT samples were then subjected to fatigue crack growth tests in the threshold and linear regions at room temperature. The test results indicate that austempering resulted in significant improvement in the yield and tensile strength as well as the fracture toughness of the material. The test results also show that, in the absence of dissolved hydrogen, the crack growth rate in the threshold and linear regions was lower in austempered samples compared to the as-received (annealed) samples. The fatigue threshold was also slightly greater in the austempered samples. In presence of dissolved hydrogen, the crack growth rate was dependent upon the $\Delta \mathrm{K}$ value. In the low $\Delta \mathrm{K}$ region $(<30 \mathrm{MPa} \sqrt{ } \mathrm{m})$, the presence of dissolved hydrogen caused the crack growth rate to be higher in the austempered samples as compared to annealed samples. Above this value, the crack growth rate was increasingly greater in the annealed specimens when compared to the austempered specimens in presence of dissolved hydrogen. It is concluded that austempering of 4140 steel appears to provide a processing route by which the strength, hardness, and fracture toughness of the material can be increased with little or no degradation in the ductility and fatigue crack growth behavior.
\end{abstract}

Keywords: fatigue crack growth rate; dissolved hydrogen; fracture toughness; austempering

\section{Introduction}

In recent years, there has been significant interest in austempering [1-5] as an alternative heat treatment process relative to traditional quenching and tempering processes. Austempering involves austentizing the steel in the fully austenitic region (above the $A_{1}$ temperature) followed by a rapid cooling into the bainitic temperature region. The steel is then held in this region for sufficient time to allow the completion of the bainitic phase transformation reaction; finally, air cooling to room temperature is conducted. The absence of a sudden quench to form martensite (as in the case of traditional quench and tempering processes) significantly reduces the thermal gradients arising in the material. This results in reduced distortion and minimization of the appearance of quench cracks. This is especially the case for small parts (like gears, bolts, and clips) used in automotive and naval structural applications that are exposed to alternating stresses. In addition, austempering can yield 
strengths like those created in traditional quench and tempering processes, especially in medium and high carbon steels.

Failure under cyclic loading (fatigue) is a very serious problem for structural components. Under cyclic loading, cracks can arise and grow; in this case, if the crack grows from a sub-critical dimension to a critical flaw size, it can lead ultimately to failure in service. The critical flaw size under a given loading condition is given by the fracture toughness of the material [6]. The fatigue crack growth rate, $(\mathrm{da} / \mathrm{dN})$, has been related to the stress intensity factor range, $(\Delta \mathrm{K})$, through the Paris equation [7]:

$$
\frac{d a}{d N}=C(\Delta K)^{m}-
$$

where $C$ and $m$ are material constants, and $\Delta K=K_{\max }-K_{\min }$, which is the difference between the maximum $\left(\mathrm{K}_{\max }\right)$ and the minimum $\left(\mathrm{K}_{\min }\right)$ stress intensity factor in a fatigue cycle. This equation has been found to be very useful in characterizing the fatigue crack growth behavior of steels.

As Figure 1 illustrates, when experimentally-measured crack growth rate data is plotted against $\Delta \mathrm{K}$ on a log scale, the graph shows three distinct regions. In Region I (the threshold region), the crack growth rate is low and deviates from the Paris equation. In Region II (the linear region), the Paris equation models the growth rate well. In Region III (the fast fracture region), the crack growth rate accelerates and again deviates from the Paris equation. In addition to these regions, there is a threshold stress intensity factor $\left(\Delta \mathrm{K}_{\mathrm{th}}\right)$, below which the crack growth rate approaches a zero value. Fatigue threshold is a very important parameter for structural design; structural components designed on the basis of fatigue threshold are expected to survive in service under cyclic loading conditions without undergoing any catastrophic failure.

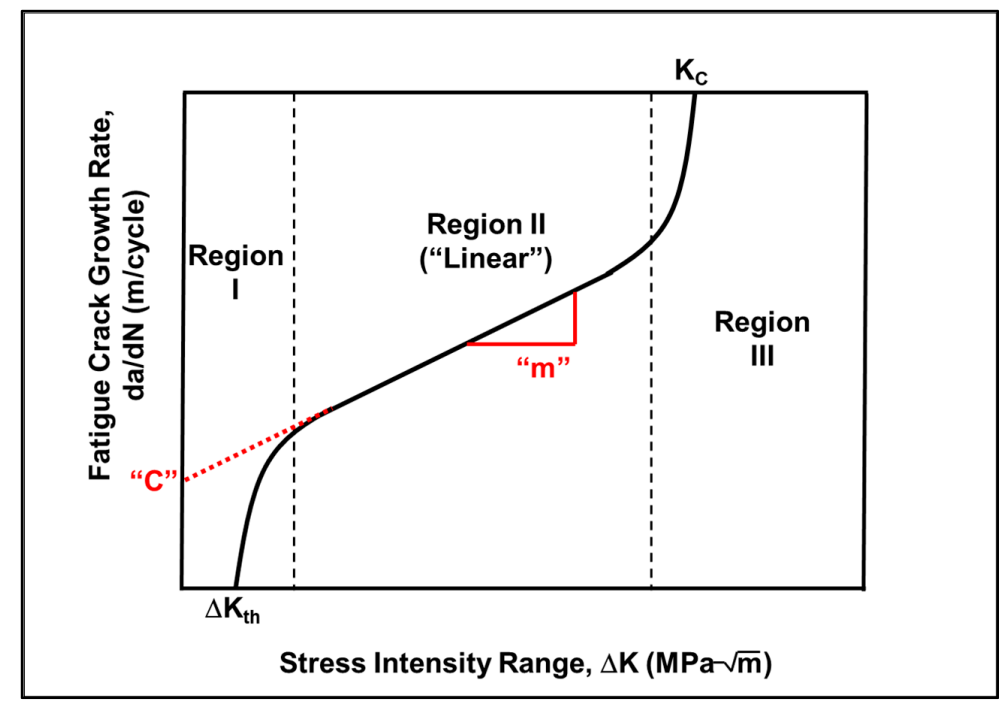

Figure 1. Fatigue Crack Growth Curve Schematic.

AISI 4140 is an extensively used commercial-grade medium-carbon, low alloy steel. It contains chromium, molybdenum, and manganese as the principal alloying elements and has high hardenability and good fatigue resistance [1,2]. This steel has many applications in mission-critical structural components [8] because of its high strength and toughness. This steel can be hardened by a variety of common heat-treatment processes to yield a wide variety of mechanical properties. While in service in critical applications, the 4140 steel can be exposed to hydrogen-bearing environments. Therefore, hydrogen-induced fatigue crack growth data for this material is needed for safe life prediction and failure-safe design of components. Although a significant number of studies have been carried out on fatigue and corrosion fatigue behavior of high strength steels, most of these studies were carried out in $3.5 \% \mathrm{NaCl}$ solutions [9-14]. 
Little information is available in literature on the influence of dissolved hydrogen on the fatigue crack growth behavior of AISI 4140 steel, especially in the austempered condition. One study [15] compared a quenched and tempered structure to an austempered structure in a gaseous hydrogen environment. This study found that the austempered samples had lower fatigue crack growth rates and higher impact toughness in the hydrogen environment. A second study [14] was conducted on a 4140-type steel that was charged with approximately $0.58 \mathrm{ppm}$ hydrogen. At low $\Delta \mathrm{K}$ values, the presence of hydrogen increased the fatigue crack growth rates up to $30 \times$. When the $\Delta K$ values exceeded $30 \mathrm{MPa} \sqrt{ } \mathrm{m}$, the fatigue crack growth rates were comparable regardless of whether hydrogen was present or not. Similar results were also observed in [16].

Previous research has shown that bainitic microstructures improve the fracture toughness in ferrous alloys $[4,5,17]$. This indicates that bainitic microstructures can possibly improve the fatigue crack growth resistance both in ambient and corrosive environments. Therefore, an investigation was undertaken to examine the influence of an austempering process on the microstructure, mechanical properties, fatigue crack growth rate, and fatigue threshold of AISI 4140 steel with dissolved hydrogen. In a previous investigation [18], the fatigue crack growth behavior of AISI 4140 steel austempered in the upper bainitic region was examined in the presence of dissolved hydrogen. This investigation is the continuation of that study; in this paper, the fatigue crack growth of AISI 4140 steel, austempered in the lower bainitic temperature region, was examined in presence of dissolved hydrogen. The testing was designed to simulate what the 4140 steel might see following a hydrogen-containing manufacturing operation and an ambient-air operating environment.

\section{Experimental Procedure}

\subsection{Material}

The material used in this investigation is the AISI 4140 steel alloy. The material was available in the form of cold-rolled and annealed plate with an identifiable rolling direction. The chemical composition of the material is reported in Table 1.

Table 1. Chemical Composition of the 4140 Alloy Steel.

\begin{tabular}{cc}
\hline Element & Composition (wt \%) \\
\hline $\mathrm{C}$ & 0.40 \\
$\mathrm{Cr}$ & 1.12 \\
$\mathrm{Mo}$ & 0.18 \\
$\mathrm{Mn}$ & 0.93 \\
$\mathrm{Si}$ & 0.33 \\
$\mathrm{~S}$ & 0.031 \\
$\mathrm{P}$ & 0.025 \\
$\mathrm{Cu}$ & 0.02 \\
$\mathrm{Ni}$ & 0.17 \\
$\mathrm{Fe}$ & Balance \\
\hline
\end{tabular}

From this steel plate, tensile specimens were prepared as per ASTM E-8 [19]. Compact Tension (CT) specimens were also manufactured with a TL orientation as per ASTM standard E-647 [20]. In the CT specimens, the width (W) was $50.8 \mathrm{~mm}$, the thickness ranged between 3 and $4 \mathrm{~mm}$, and the notch length (as measured from the centerline of the loading holes to the tip of the machined notch) was $15.24 \mathrm{~mm}$. Additional compact tension samples were prepared for fracture toughness testing as per ASTM standard E-399 [6]; for these samples, the width was $40 \mathrm{~mm}$ and the thickness was $20 \mathrm{~mm}$.

\subsection{Heat Treatment and Tensile Testing}

To understand the effect of austempering, all of the test samples (tensile and CT) were divided into two batches. The first batch of samples was left in the annealed (as-received) condition. The second 
batch of samples were heat-treated to produce an austempered condition. This was accomplished by initially austenitizing these samples at $882^{\circ} \mathrm{C}$ for $1 \mathrm{~h}$. The samples were then immediately transferred to a molten salt bath at $332^{\circ} \mathrm{C}$, where they were held for $1 \mathrm{~h}$. The austempering in this $332{ }^{\circ} \mathrm{C}$ temperature region produced the desired lower bainitic structure. The specimens were then removed from the salt bath and were allowed to air cool to room temperature.

All of the tensile samples (annealed as well as heat-treated) were tested as per ASTM E-8 [19]. The tests were performed at a constant engineering strain rate of $4 \times 10^{-4} \mathrm{~s}^{-1}$ on a servo-hydraulic Material Test System (MTS) 810 test machine. All of the samples were tested at room temperature and ambient atmosphere. Load and displacement plots were obtained on an X-Y recorder; from these load-displacement diagrams, the yield strength, ultimate tensile strength, and \% elongation values were calculated. Four samples were tested in each condition.

\subsection{Pre-Cracking of CT Specimens}

To minimize the amount of time between hydrogen charging and testing, all of the CT specimens were pre-cracked before charging occurred. Pre-cracking was performed in the MTS 810 servo-hydraulic test machine in the load control mode at room temperature and ambient atmosphere. For the fatigue threshold specimens, a cyclic loading frequency of five cycles per second $(5 \mathrm{~Hz})$ was used to produce a 2-mm sharp crack front in accordance with ASTM standard E-647 [20]. The CT samples for the fracture toughness tests were pre-cracked in fatigue at a $\Delta \mathrm{K}$ level of $10 \mathrm{MPa} \sqrt{ } \mathrm{m}$ with a load ratio of $\mathrm{R}=0.10$. This produced a 2-mm sharp crack in accordance with the ASTM standard E-399 [6].

\subsection{External Hydrogen Charging}

To understand the effect of hydrogen and austempering, all of the pre-cracked Compact Tension (CT) specimens were divided into one of the four sets listed in Table 2.

Table 2. Matrix of Material Conditions for the 4140 Alloy CT Specimens.

\begin{tabular}{ccc}
\hline Set & Material & Externally Charged with Hydrogen? \\
\hline "A" & Annealed & No \\
"B" & Annealed & Yes \\
"C" & Austempered $\left(332^{\circ} \mathrm{C} / 1 \mathrm{~h}\right)$ & No \\
"D" & Austempered $\left(332^{\circ} \mathrm{C} / 1 \mathrm{~h}\right)$ & Yes \\
\hline
\end{tabular}

As detailed in Table 2, two of the sets were set aside; these are referred to as the "Uncharged" specimens. The other two sets were externally charged with hydrogen ("Charged" specimens). Charging was accomplished using two DC power supplies (Agilent E3616A and Sorensen XPL-30-2D) that were capable of providing a steady source of electric current of about 1-1.5 A and a 4-mm stainless steel bar as the anode; the stainless steel bar was chosen as it was an effective, low-cost alternative to platinum. The samples to be charged with hydrogen were used as the cathode (Figure 2). Deionized water, obtained from Barnstead Nanopure Diamond D11911, having a resistivity of about $16.5 \pm 0.5 \mathrm{M} \Omega-\mathrm{cm}$, was used to dissolve sodium hydroxide so that a $1 \mathrm{~N}$ solution was obtained. Dissolution was done to avoid the uptake of deleterious ions during the external hydrogen charging [21]. This $1 \mathrm{~N}$ solution was used as the electrolyte for charging hydrogen into the samples. The current density was maintained steady at $300 \mathrm{~A} / \mathrm{m}^{2}$. The samples were charged with hydrogen for 150, 200, and $250 \mathrm{~h}$ at room temperature. A minimum of three samples were charged from each set for each of the given exposure times; in each case, the sample was tested within 15 min after charging was complete.

In addition, six special CT samples were created for the purpose of measuring the hydrogen concentration in the annealed and austempered conditions. These samples were prepared in the manner detailed previously. 


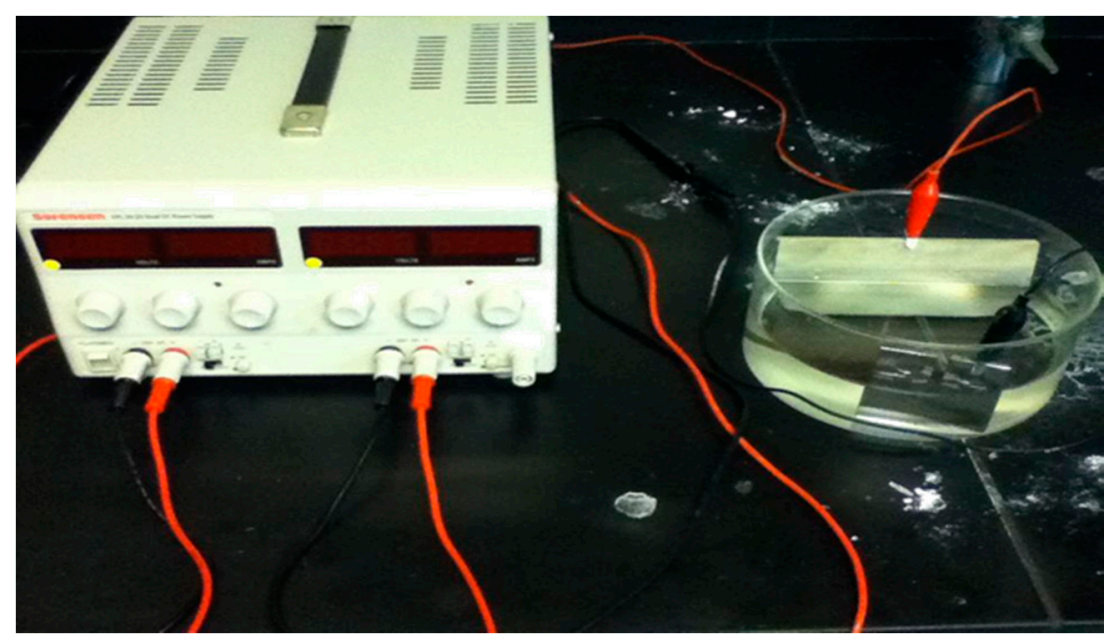

Figure 2. Experimental setup of external hydrogen charging.

\subsection{Hydrogen Concentration Analysis}

The six special analysis samples were analyzed for the hydrogen concentration via a Vacuum Hot Extraction method using an NRC Model 917 unit. The testing was conducted at Luvak Laboratories (Boylston, MA, USA) within $24 \mathrm{~h}$ of charging. Each charged sample was first weighed and cleaned with ether to remove surface contaminants. Each sample was then placed into an evacuated chamber surrounded by induction heating coil. Each sample was heated to a point below the melting point of the sample (approximately $1150{ }^{\circ} \mathrm{C}$ ) to degas hydrogen from the sample. The hydrogen was collected in a separate chamber in the system, and was measured by a McLeod gauge. All of the measurements were accurate to $\pm 0.1 \mathrm{ppm}$.

\subsection{Fatigue Testing}

Within 15 min after completion of charging, each fatigue sample was tested on a MTS 810 servo-hydraulic test machine in the load control mode at room temperature and in ambient atmosphere. All of the fatigue testing was carried out at a cyclic loading frequency of five cycles per second $(5 \mathrm{~Hz})$. A constant amplitude sinusoidal waveform was applied and the tests were carried out at a load ratio $\mathrm{R}=\mathrm{K}_{\min } / \mathrm{K}_{\max }=0.10$. Crack lengths were measured on the specimen surface using an optical microscope without interrupting the test; at the same time, the number of fatigue cycles was also recorded. The crack growth rate, da/dN, was determined as per ASTM standard E-647 [20]. Four samples from each material condition, as listed in Table 2, were tested and averaged for the values reported in this paper.

The threshold was obtained using the load-shedding, decreasing $\Delta \mathrm{K}$ procedure detailed in ASTM E-647 [20]; the load was periodically decreased until the crack growth rate reached a level of $10^{-10} \mathrm{~m} /$ cycle. The reduction of load at a given $\Delta \mathrm{K}$ level was done in such a way that no more than $10 \%$ of the load was reduced for that $\Delta \mathrm{K}$ level. This load shedding was also done after the crack has grown at least $0.5 \mathrm{~mm}$ at the previous $\Delta \mathrm{K}$ level. In this way, any retardation effect (due to a previous higher $\Delta \mathrm{K}$ level) was avoided.

\subsection{Fracture Toughness Test}

Within 15 min after completion of charging, each fracture toughness specimen was loaded in tension in a servo-hydraulic MTS test machine; the load-displacement diagrams were obtained using a clip gauge in the knife edge attachment on the specimen. From these load-displacement diagrams, $\mathrm{P}_{\mathrm{Q}}$ values were calculated using the $5 \%$ secant deviation technique. From these $\mathrm{P}_{\mathrm{Q}}$ values, the $\mathrm{K}_{\mathrm{Q}}$ values were determined using the standard stress intensity factor calibration function for the $\mathrm{CT}$ 
specimens. Since these $\mathrm{K}_{\mathrm{Q}}$ values satisfied all of the requirements for a valid $\mathrm{K}_{\mathrm{IC}}$ as per ASTM standard E-399 [6], they were judged to be valid $\mathrm{K}_{\mathrm{IC}}$ values. Four samples from each material condition listed in Table 2 were tested and averaged for the values reported in this paper.

\section{Results and Discussion}

\subsection{Microstructure}

The microstructure of the 4140 steel alloy in the annealed condition showed a mixed ferrite + pearlite structure; very fine needles of pearlite were observed in the matrix (Figure 3) X-ray diffraction [18] as well as transmission electron microscopy (TEM) examinations were carried out. Both techniques detected only body-centered cubic (BCC) phases in the material. No retained austenite was detected (via XRD or TEM) or observed in prepared metallographic specimens.

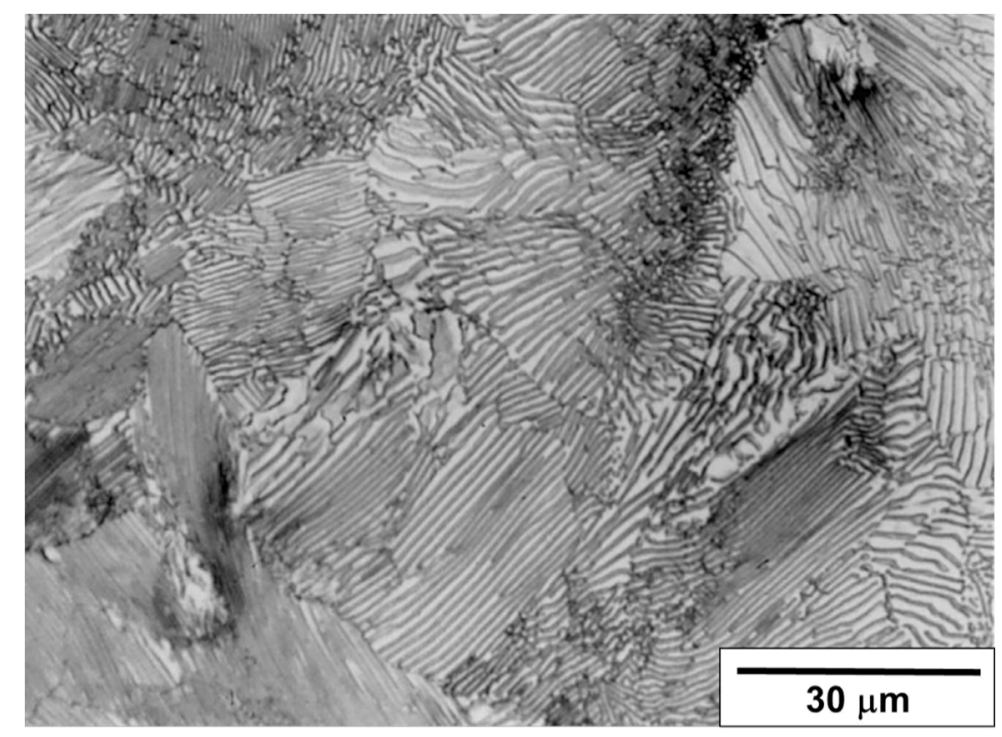

Figure 3. Fine Pearlite Observed in the Annealed AISI 4140 Steel Alloy (Sodium Bisulfate etch).

The microstructure of the austempered 4140 samples is shown in the Figure 4 . It shows the presence of lower bainite (blue-colored phase) and a limited number of isolated pockets of martensite (brown-colored phase) in the microstructure. These arose even though the samples were austempered at a temperature above the $\mathrm{M}_{\mathrm{s}}$ (Martensite Start) temperature of the material. This was attributed to segregation effects from the alloying elements present in the steel. The carbides of alloying elements like $\mathrm{Cr}, \mathrm{Mo}$, and $\mathrm{Mn}$ tend to segregate to the intercellular regions. In these segregated regions, the bainitic reaction associated with the austenite decomposing into ferrite and carbide becomes sluggish; therefore, complete transformation does not take place during the processing time. Upon cooling, these untransformed regions can form martensitic structures. Optically, a very small amount $(<1 \%)$ of retained austenite (white phase) was also observed in the material; however, no retained austenite was detected using either XRD or TEM. Therefore, it is concluded that the amount of austenite present is so small as to have no effect upon the resultant hydrogen concentration or properties in the austempered material. 


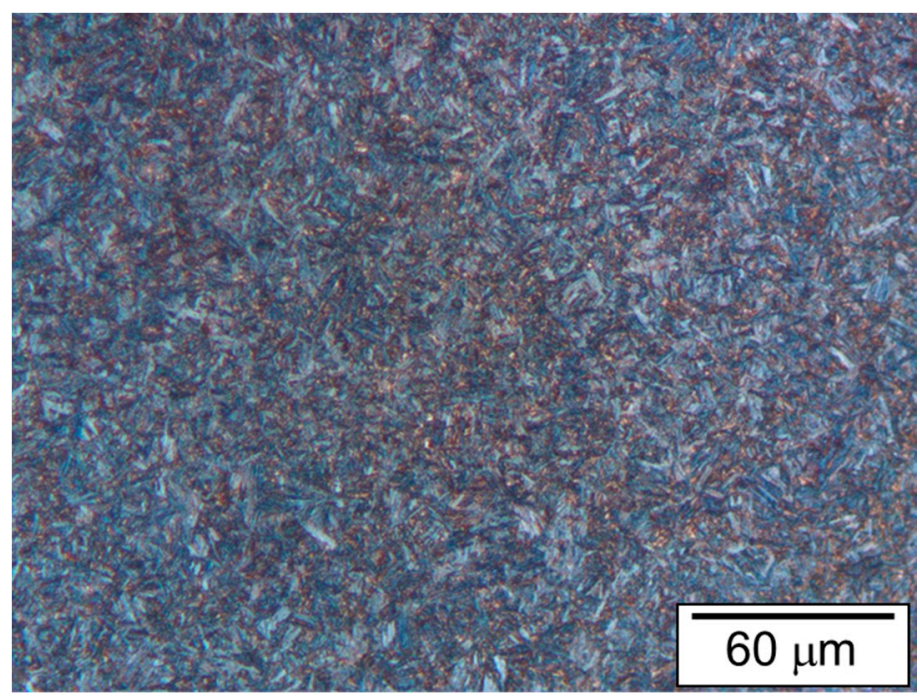

Figure 4. The Microstructure of the Austempered AISI 4140 Steel Alloy (Sodium Bisulfate etch).

\subsection{Mechanical Properties}

The mechanical properties of the 4140 steel are reported in Table 3. Statistical analysis of this data showed that the austempering process had significantly increased the hardness, as well as both the yield and tensile strengths, without any significant reduction in the ductility. In addition, the fracture toughness shows a statistically slight improvement as well. Thus, the austempered microstructure of lower bainite with a limited amount of martensite has increased the strength, hardness, and fracture toughness without any loss of ductility in the AISI 4140 steel. Furthermore, the strength and hardness of the material was comparable to that obtained by a traditional quenching and tempering process in AISI 4140 steel [22].

Table 3. Mechanical Properties of AISI 4140 Alloy.

\begin{tabular}{cccccc}
\hline $\begin{array}{c}\text { Material } \\
\text { Condition }\end{array}$ & $\begin{array}{c}\text { Yield Strength } \\
\mathbf{( M P a})\end{array}$ & $\begin{array}{c}\text { Ultimate Tensile } \\
\text { Strength }(\mathbf{M P a})\end{array}$ & $\begin{array}{c}\mathbf{\%} \\
\text { Elongation }\end{array}$ & $\begin{array}{c}\text { Hardness } \\
\left.\mathbf{( H R}_{\mathbf{c}}\right)\end{array}$ & $\begin{array}{c}\text { Fracture Toughness } \\
\mathbf{( M P a} \sqrt{ } \mathbf{m})\end{array}$ \\
\hline $\begin{array}{c}\text { Annealed } \\
\text { Austempered }\end{array}$ & $757 \pm 20$ & $1031 \pm 5$ & 5.6 & $28 \pm 1$ & $65 \pm 2$ \\
$\left(332^{\circ} \mathrm{C} / 1 \mathrm{~h}\right)$ & $1481 \pm 12$ & $1646 \pm 9$ & 5.5 & $45 \pm 1$ & $72 \pm 6$ \\
\hline
\end{tabular}

\subsection{Hydrogen Concentration}

Table 4 shows the effect of charging times on the concentration of dissolved monoatomic hydrogen in the 4140 steel alloy. As this table shows, the amount of dissolved hydrogen increases as the charging time increases for both the annealed and austempered conditions.

Table 4. The Effect of Charging Time on the Dissolved Hydrogen Content of the 4140 Steel.

\begin{tabular}{ccc}
\hline Material Condition & Hydrogen Charging Time (Hours) & Measured Hydrogen Content (ppm) \\
\hline & 150 & 0.7 \\
Annealed & 200 & 1.5 \\
& 250 & 2.9 \\
\hline \multirow{2}{*}{ Austempered $\left(332^{\circ} \mathrm{C} / 1 \mathrm{~h}\right)$} & 150 & 1.6 \\
& 200 & 3.6 \\
\hline
\end{tabular}


Additionally, the table shows that the austempered samples were found to have over a two-fold increase in the amount of dissolved hydrogen compared to the annealed samples for a given charging time. This can be attributed to the small amount of martensite present in the microstructure after austempering. Martensitic structures are known to have a higher dislocation density when compared to other phases like ferrite, pearlite, or bainite [1,2]. These dislocations can act as hydrogen traps in the material $[16,23,24]$. The presence of these traps also reduces the diffusivity of hydrogen to a lower value than what was estimated by equations based upon the concentration [25]. One previous investigation [16] also concluded that that the diffusivity of hydrogen in steel cannot be determined by application of Fick's law in the presence of traps in the material.

In addition to dislocation density effects, the diffusion coefficient of hydrogen appears to be affected by the presence of martensite as well. An earlier investigation on Cr-Mo steels [26] showed that the diffusion coefficient of hydrogen in martensite was marginally lower than that in bainite. Further, a recent study on hydrogen-induced cracking in steels [15] showed that the diffusion coefficient decreases as the strength of the alloy increased.

Thus, it can be concluded that the presence of martensite in the austempered alloy resulted in a larger number of dislocations, which created a large number of hydrogen traps in the material. This, in turn, resulted in higher concentration of dissolved hydrogen content in the austempered samples compared to the annealed sample.

\subsection{Influence of Austempering on the Crack Growth Behavior of Uncharged 4140 Steel}

Figure 5 compares the fatigue crack growth behavior in the threshold region (Region I) for the annealed and austempered conditions; this data is for the samples without dissolved hydrogen (Sets " $\mathrm{A}$ " and " $\mathrm{C}$ " in Table 2). Table 5 details the threshold stress intensity values for these materials. As this figure and table illustrate, the fatigue crack growth rate of the annealed samples in the near-threshold region was higher than the austempered samples; additionally, the $\Delta \mathrm{K}_{\text {th }}$ of the annealed samples was lower than that of the austempered samples in this region as well.

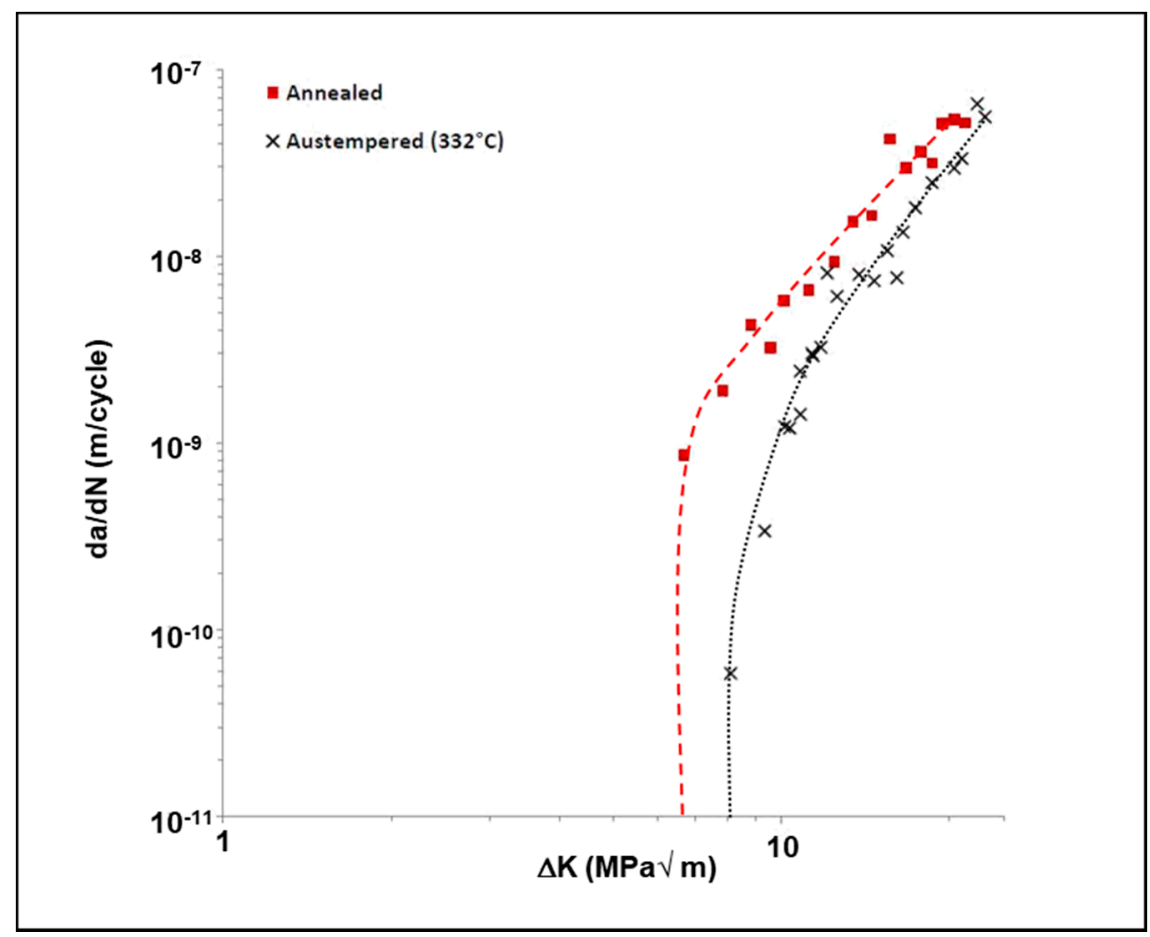

Figure 5. The Effect of Austempering on the Fatigue Crack Growth Rate of Uncharged 4140 Steel in the Threshold Region. 
Table 5. Experimentally-Determined Values of $\Delta \mathrm{K}_{\mathrm{th}}$ for the Uncharged 4140 Steel Alloy.

\begin{tabular}{cc}
\hline Material Condition & $\Delta \mathbf{K}_{\text {th }}(\mathbf{M P a} \sqrt{ } \mathbf{m})$ \\
\hline Annealed & 6.68 \\
Austempered $\left(332{ }^{\circ} \mathrm{C} / 1 \mathrm{~h}\right)$ & 8.12 \\
\hline
\end{tabular}

The lower crack growth rate in the austempered samples was an interesting result and cannot be attributed to the lower crack closure stress intensity factor $\left(\mathrm{K}_{\mathrm{op}}\right)$ in this material. During cyclic loading, the compressive stress in the crack tip region will cause the crack to remain partially closed during the unloading part of the fatigue cycle. This stress intensity factor (for crack closure) is often defined as $\mathrm{K}_{\mathrm{op}}$. Thus, the effective stress intensity factor, $\Delta \mathrm{K}_{\text {eff }}$, is a measure of crack driving force and is given by $\Delta \mathrm{K}_{\text {eff }}=\mathrm{K}_{\max }-\mathrm{K}_{\mathrm{op}}$. This crack-opening stress intensity factor depends on the cyclic plastic zone size, which is inversely proportional to the yield strength of the material. Thus, the $\mathrm{K}_{\mathrm{op}}$ value decreases as the material strength increases.

In this study, the cyclic plastic zone size was calculated using Rice's formula [27] for each set of specimens at the different charging conditions, based upon where the maximum transgranular (or intergranular) feature was observed. However, these calculations yielded identical results for all of the materials; the cyclic plastic zone sizes were approximately 14-22 $\mu \mathrm{m}$. Further, the austempered samples had a significantly higher yield strength than the annealed samples (Table 3). This means that the $K_{\mathrm{op}}$ value will be lower in the austempered samples as compared to the annealed samples. Therefore, it would be expected that a higher crack driving force $\left(\Delta \mathrm{K}_{\text {eff }}\right)$ would be present in the austempered samples. Consequently, a higher near-threshold fatigue crack growth rate and lower fatigue threshold $\left(\Delta \mathrm{K}_{\mathrm{th}}\right)$ would also be expected for the austempered samples.

However, the opposite was observed in the samples in this study: a lower crack growth rate and higher $\Delta \mathrm{K}_{\mathrm{th}}$ were found for the austempered samples. This unique behavior is hypothesized to be due to the following two factors:

- First, the austempering process has increased the fracture toughness of the material due to the presence of a microstructure containing a large amount of lower bainite. The lower bainitic microstructure increases the fracture toughness of the material [3-5]. The higher fracture toughness is indicative of a greater crack growth resistance in this material. This, in turn, causes a lower fatigue crack growth rate and a higher fatigue threshold in the material.

- Secondly, the austempered samples had a very fine-scale microstructure consisting of lower bainite with a limited amount of tempered martensite. A lower bainitic structure has a much finer grain size than upper bainite or pearlite. This creates additional resistance to crack growth since the crack tip encounters large number of fine scale grain boundaries. This, in turn, reduces the crack propagation rate because the crack grows along a longer, more torturous path.

Figure 6 shows the fatigue crack growth behavior of the uncharged annealed and austempered specimens in the linear region (Region II). This is further shown by the data in Table 6. The austempered material had a much lower value of the Paris constant " $\mathrm{C}$ " and a slightly higher " $\mathrm{m}$ " value. It is evident from the plot that the austempered specimens have a lower crack growth rate than the annealed specimens. Again, the general expected trend is that the fatigue crack growth rate increases with a higher strength and hardness. However, the austempered samples in the present study again have a lower crack growth rate despite the higher hardness and strength; this behavior is similar to what was seen previously in the threshold region. The behavior is also attributed to the increased crack growth resistance provided by the lower bainitic microstructure. 
Table 6. Comparison of Paris Constants for the Uncharged 4140 Steel Alloy.

\begin{tabular}{ccc}
\hline \multirow{2}{*}{ Material Condition } & \multicolumn{2}{c}{ Paris Law Constant } \\
\cline { 2 - 3 } & $\mathbf{C}$ & $\mathbf{m}$ \\
\hline Annealed & $1 \times 10^{-10}$ & 2.08 \\
Austempered $\left(332^{\circ} \mathrm{C} / 1 \mathrm{~h}\right)$ & $5 \times 10^{-11}$ & 2.14
\end{tabular}

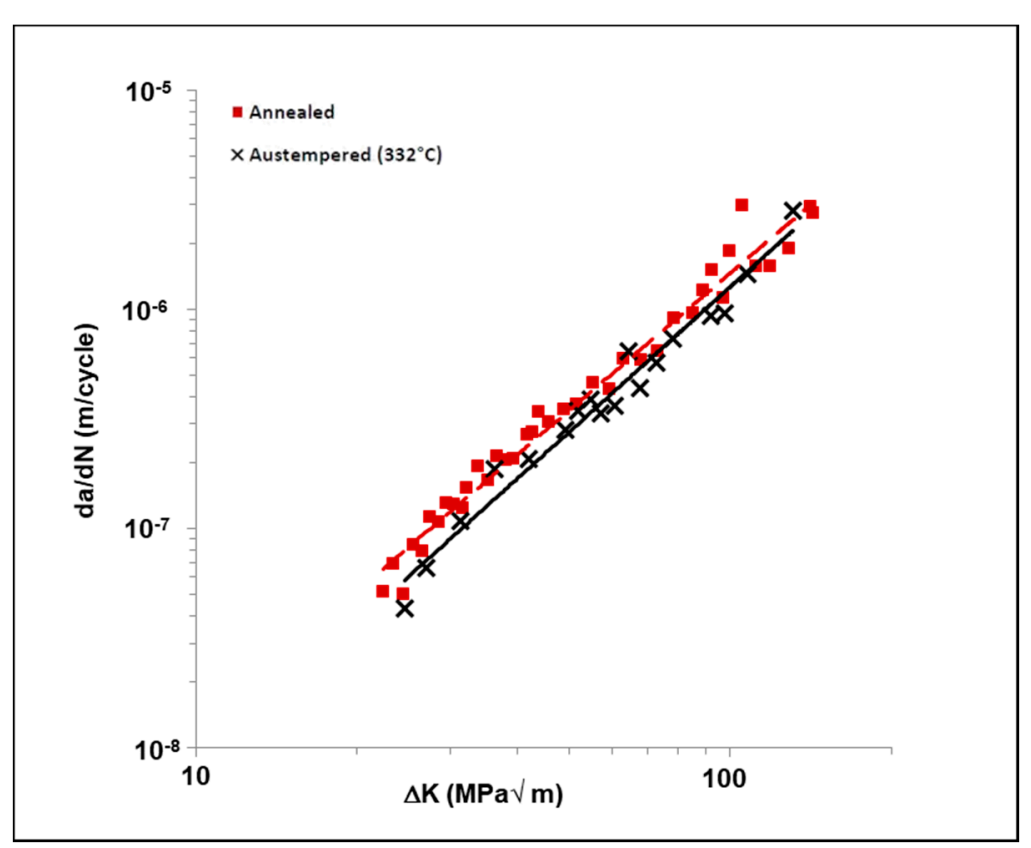

Figure 6. The Effect of Austempering on the Fatigue Crack Growth Rate of Uncharged 4140 Steel in the Linear Region.

Hence, upon comparing the fatigue crack growth rates in the linear region (Figure 6), as well as in the threshold region (Figure 5), it can be concluded that the lower bainitic microstructure provides an improved fatigue crack growth resistance in 4140 steels when dissolved hydrogen is not present. Similar results have been reported for a series of low alloy steels [28].

\subsection{Influence of Hydrogen on the Fatigue Crack Gowth Behavior of 4140 Steel}

Figure 7 shows the fatigue crack growth behavior of the annealed samples in the linear region in presence of dissolved hydrogen; for comparison, the crack growth behavior of the annealed samples without dissolved hydrogen is also plotted in the same figure. The data in Figure 7 shows that the presence of dissolved hydrogen causes a large amount of variation in the crack growth rate data. In addition, the presence of hydrogen appears to increase the average crack growth rate at $\Delta \mathrm{K}$ values that are greater than $60 \mathrm{MPa} \sqrt{ } \mathrm{m}$. Figure 7 also shows that the hydrogen charging time does not have any significant effect on the crack growth rate, given the high degree of variation in the data. 


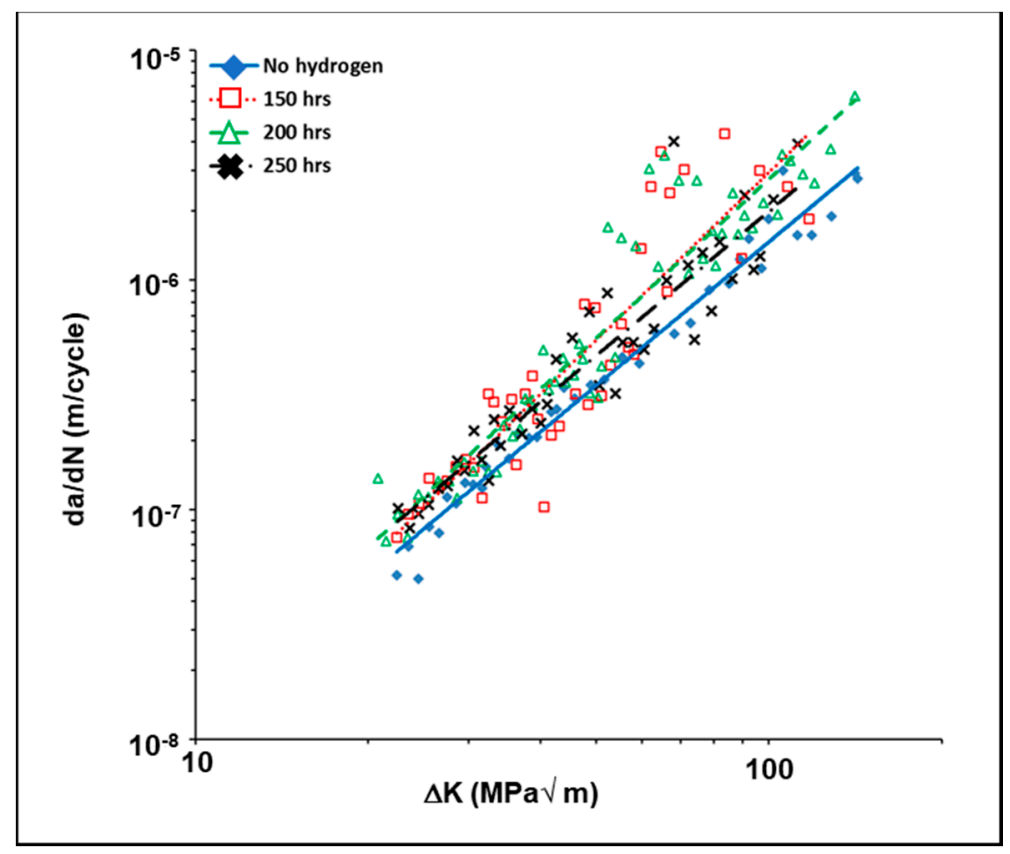

Figure 7. The Effect of Hydrogen Charging Time on the Fatigue Crack Growth Rate in the Linear Region for the Annealed 4140 Steel Samples.

Figure 8 shows the fatigue crack growth behavior of the austempered samples in the linear region in the presence of dissolved hydrogen; again, for comparison purposes, the crack growth behavior of the austempered samples without dissolved hydrogen is also plotted in the same figure. Similar to that seen in Figure 7, Figure 8 shows that the hydrogen charging time does not have any significant effect on the crack growth rate of the austempered samples. However, in contrast to the data in Figure 7, Figure 8 shows that the presence of dissolved hydrogen does not cause a large amount of variation in the crack growth rate data. In addition, Figure 8 shows that the presence of dissolved hydrogen increases the crack growth rate significantly at $\Delta \mathrm{K}$ values below $30 \mathrm{MPa} \sqrt{ } \mathrm{m}$. Thus, the effect of hydrogen is relatively important when the contribution of other mechanisms is small. When $\Delta \mathrm{K}$ is low, there is little stress built up at the crack tip; the effect of hydrogen on crack growth is increased since there is little stress to provide increased energy for the propagation of a crack.

The results in Figures 7 and 8 agree with those from two published research studies $[14,16]$ on 4100-series steel alloys charged with hydrogen and tested in laboratory air. They found that the crack growth rates in the range of $10^{-5}$ to $10^{-7} \mathrm{~m} /$ cycle were increased in the hydrogen-charged samples when compared to the uncharged samples.

Table 7 details the fatigue threshold of both the annealed and austempered 4140 alloy as a function of dissolved hydrogen content. The data in this table shows that there are only minor differences in the threshold values of the annealed and austempered samples; in addition, all these values are low regardless of hydrogen content. This is an important result, as it shows that austempering can be used to provide improved strength properties while avoiding a significant reduction in fatigue crack resistance; this combination is not usually observed in most materials. 


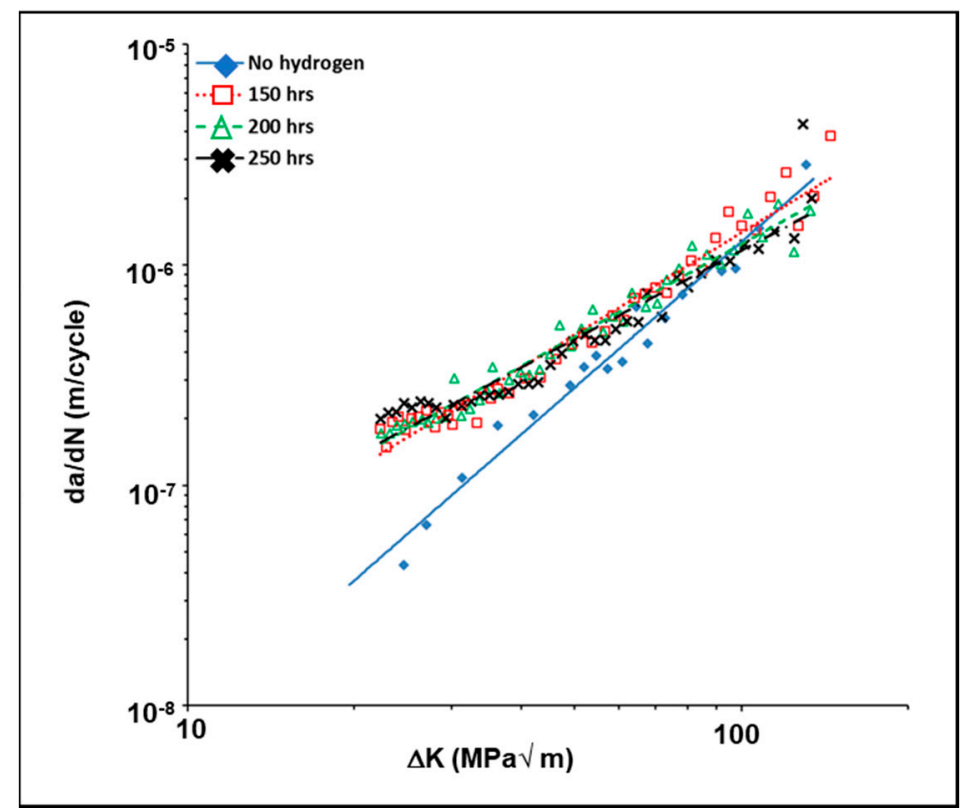

Figure 8. The Effect of Hydrogen Charging Time on the Fatigue Crack Growth Rate in the Linear Region for the Austempered 4140 Steel Samples.

Table 7. The Effect of Hydrogen-Charging Time on the $\Delta \mathrm{K}_{\mathrm{th}}$ for the 4140 Steel Alloy.

\begin{tabular}{cccc}
\hline Material Condition & $\begin{array}{c}\text { Hydrogen Charging } \\
\text { Time (Hours) }\end{array}$ & $\begin{array}{c}\text { Hydrogen } \\
\text { Concentration }(\mathbf{p p m})\end{array}$ & $\begin{array}{c}\Delta \mathbf{K}_{\mathbf{t h}} \\
(\mathbf{M P a} \sqrt{ } \mathbf{m})\end{array}$ \\
\hline \multirow{3}{*}{ Annealed } & 0 & - & 6.68 \\
& 150 & 0.7 & 5.58 \\
& 200 & 1.5 & 5.49 \\
Austempered $\left(332^{\circ} \mathrm{C} / 1 \mathrm{~h}\right)$ & 250 & 2.9 & 7.85 \\
\hline & 150 & - & 8.12 \\
& 200 & 1.6 & 6.59 \\
& 250 & 3.6 & 6.17 \\
\hline
\end{tabular}

Table 7 also illustrates that, as the hydrogen concentration increases, the fatigue threshold decreases slightly in the austempered sample. This is the expected result, and it is believed to be due to the increased amount of hydrogen that will cause lattice dilation in the steel. This, in turn, increases the strain fields and internal energy, resulting in a greater driving force for crack propagation; this results in a lower threshold stress that must be achieved to grow the crack.

Table 7 also shows that, in the annealed samples, the dissolved hydrogen content did not have any significant effect. The reason for this has not been conclusively determined. It could be a result of the large variation in the experimental data. Or, it may be due to a threshold limit, above which the presence of hydrogen could be beneficial to certain microstructures. Further investigation is necessary to understand these results and is in progress.

Figures 9-11 compare the fatigue crack growth behavior in the linear region for the annealed and austempered specimens as a function of the charging time (dissolved hydrogen content.) Interestingly, all of these figures show that, in the low $(<30 \mathrm{MPa} \sqrt{ } \mathrm{m}) \Delta \mathrm{K}$ region, the annealed specimens have a lower crack growth rate than the austempered specimens. As the $\Delta \mathrm{K}$ values increase beyond approximately $30 \mathrm{MPa} \sqrt{ } \mathrm{m}$, a transition stress intensity factor range exists where the annealed specimens have an increasingly higher crack growth rate than austempered specimen. This observation indicates that, in the higher $\Delta \mathrm{K}$ regions, the austempered specimens are more resistant to crack growth in hydrogen-charged atmospheres. This was unexpected, as several investigators [28,29] have reported 
that the embrittlement effects of hydrogen are more severe in the case of high strength steels. Due to the higher strength and hardness of the alloy in austempered conditions, hydrogen embrittlement would be expected to have a stronger effect. It is hypothesized that the lower bainitic microstructure developed during the austempering process is counteracting this embrittling effect; the increased tortuosity of the crack path is believed to be key.

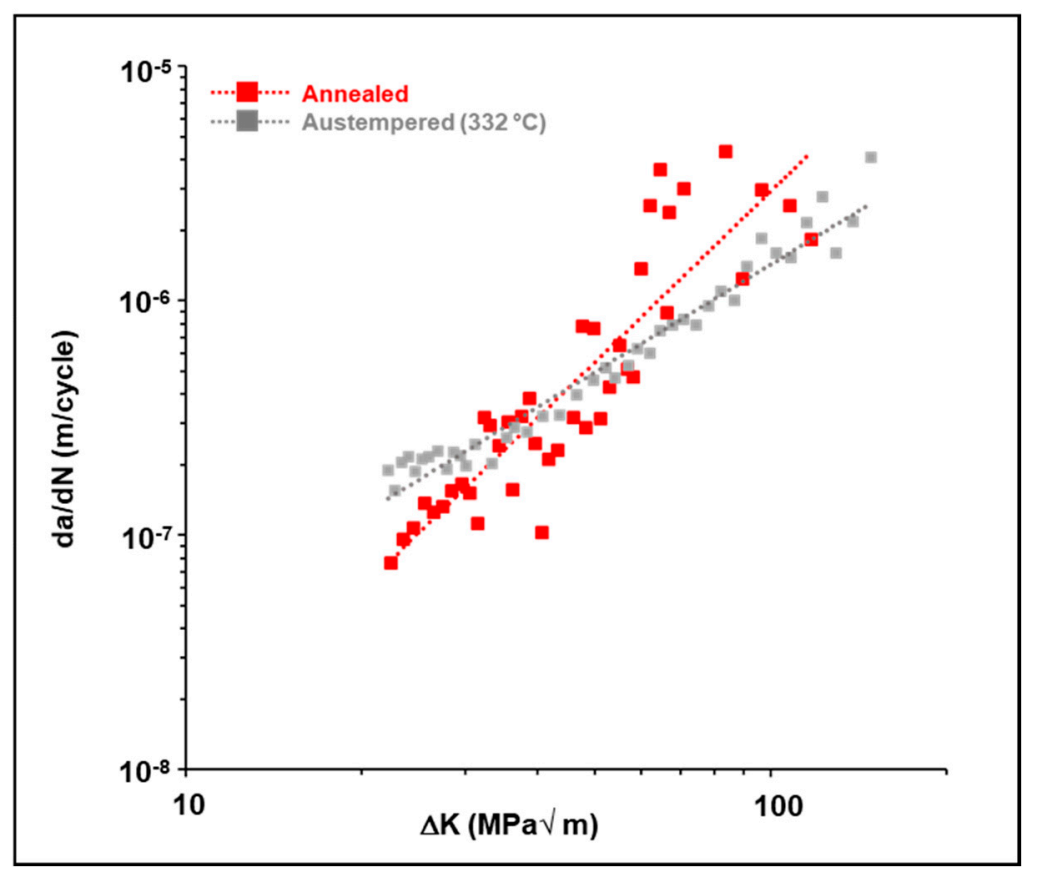

Figure 9. The Effect of Austempering on the Fatigue Crack Growth Rate of the 4140 Steel Hydrogen-Charged for $150 \mathrm{~h}$.

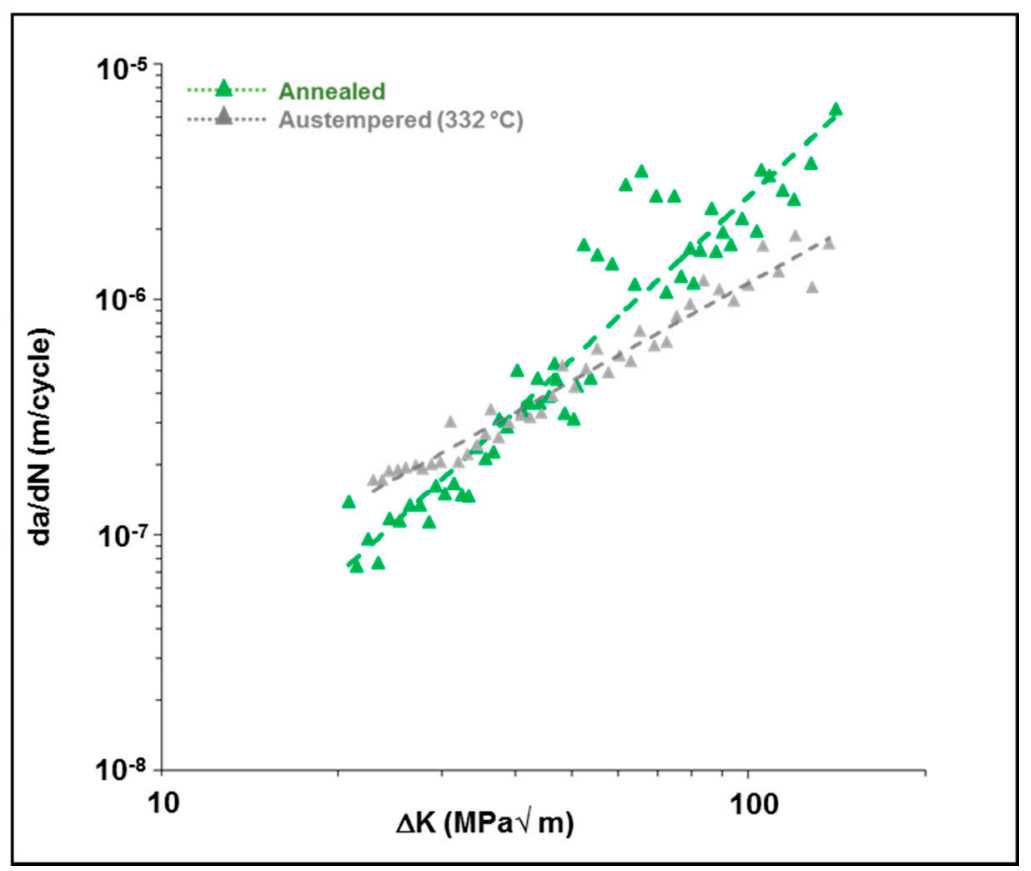

Figure 10. The Effect of Austempering on the Fatigue Crack Growth Rate of the 4140 Steel Hydrogen-Charged for $200 \mathrm{~h}$. 


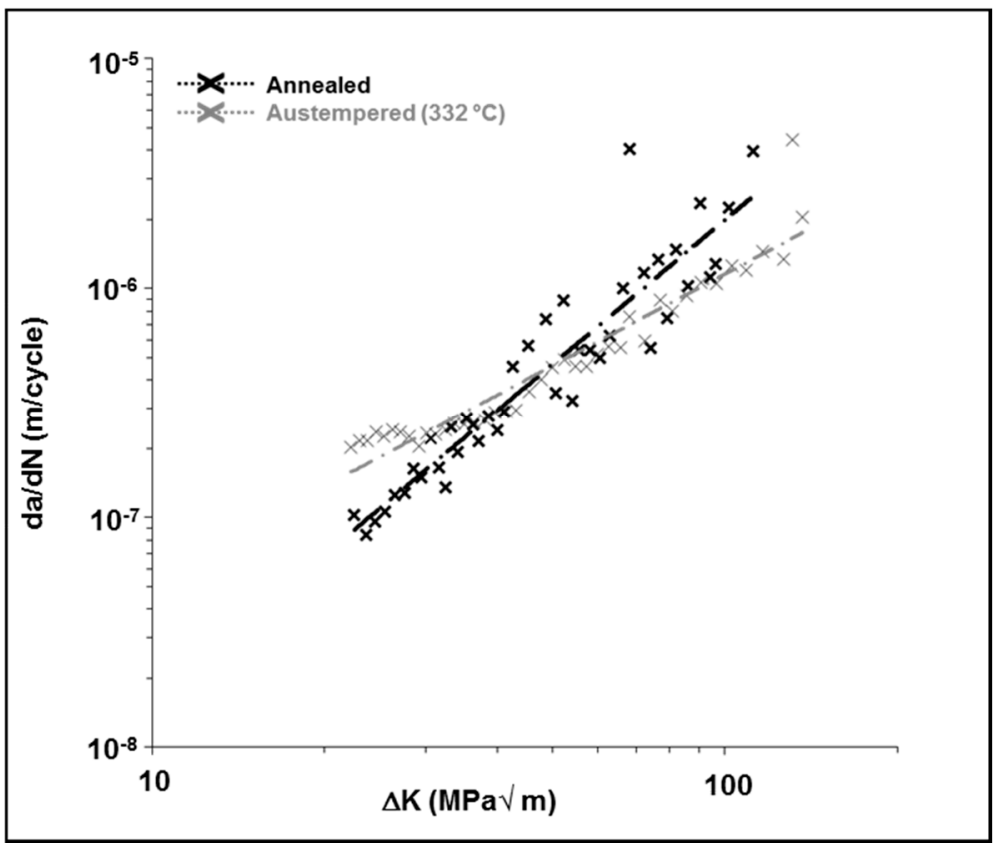

Figure 11. The Effect of Austempering on the Fatigue Crack Growth Rate of the 4140 Steel Hydrogen-Charged for $250 \mathrm{~h}$.

\subsection{Fractography}

The fracture surfaces that are associated with the annealed 4140 alloy samples are shown in Figure 12. As this figure shows, charging with hydrogen only slightly changes the fracture surface morphology. The fracture surfaces of the hydrogen-charged samples (Figure 12b) appear to have limited ductile tearing with a more flat-like appearance as compared to the uncharged samples (Figure 12a). This correlates well with experimentally-determined fatigue crack growth rate data shown in Figures 6 and 7, which show the relative closeness of the fatigue curves to one another regardless of the charging condition.

Figure 13 shows the fracture surfaces associated with the austempered 4140 alloy samples at low $\Delta \mathrm{K}$ values. Several interesting characteristics were observed. Similar to that seen in Figure 12a, the fracture surface in the uncharged samples (Figure 13a) have little ductile tearing and are relatively flat in morphology. However, in contrast to those seen in Figure 12b, Figure 13b shows that the hydrogen-charged austempered samples are characterized by both intergranular and transgranular features. Intergranular features appear increasingly prominently as the $\Delta \mathrm{K}$ values decrease in the charged austempered samples. This also agrees well with the experimental fatigue crack growth data, which shows that the austempered samples that are charged with hydrogen have fatigue crack growth rates that are faster and fatigue thresholds that are lower when compared to those in the annealed material at low $\Delta \mathrm{K}$ values.

Figure 14 shows the fracture surfaces associated with the austempered 4140 alloy samples at high $\Delta \mathrm{K}$ values. As this figure details, the fracture surface in the uncharged samples (Figure 14a) are very similar to those in the charged samples (Figure 14b). Both fracture surfaces are characterized by a large number of transgranular features. Once again, this agrees well with the experimental fatigue crack growth data for high $\Delta \mathrm{K}$ values, which show that the fatigue crack growth rates for the charged and uncharged austempered material are similar at high $\Delta \mathrm{K}$ values. 


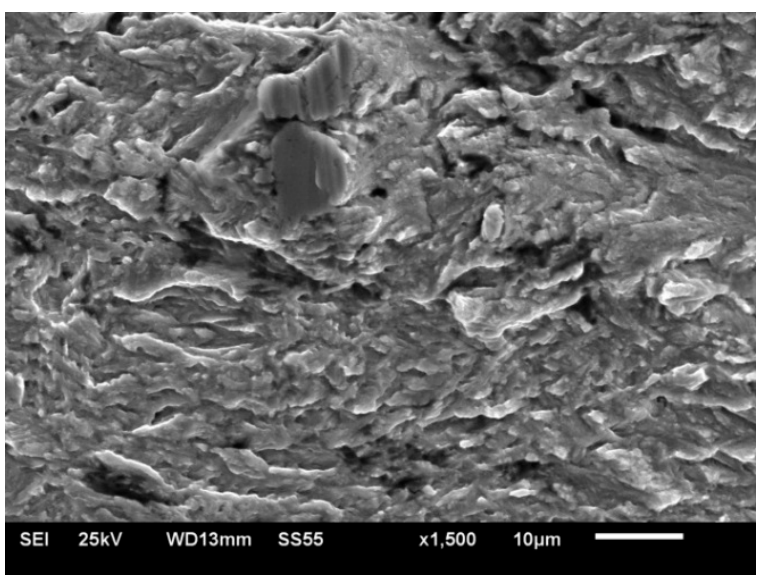

(a)

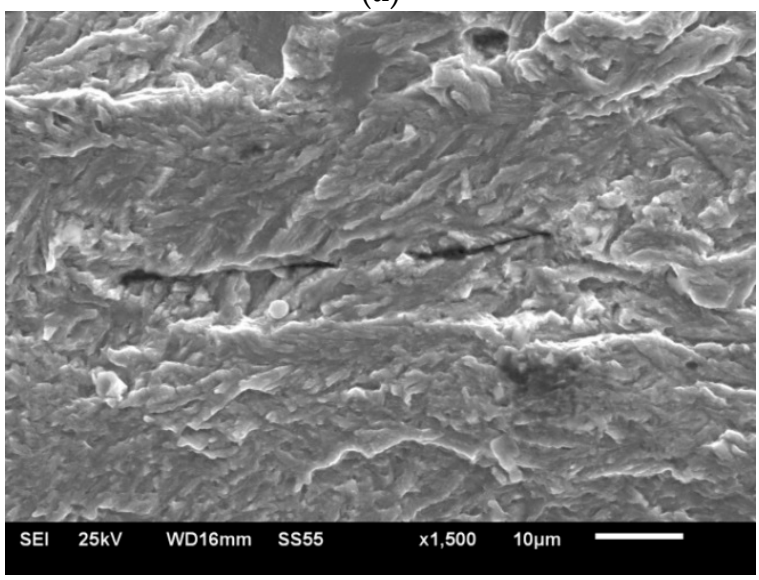

(b)

Figure 12. Typical Fatigue Fracture Surface Features Present in the Annealed 4140 Samples. $(\Delta \mathrm{K}=12 \mathrm{MPa} \sqrt{ } \mathrm{m}$; crack growth direction was from top to bottom of photos). (a) Uncharged (No Hydrogen); (b) Hydrogen-Charged.

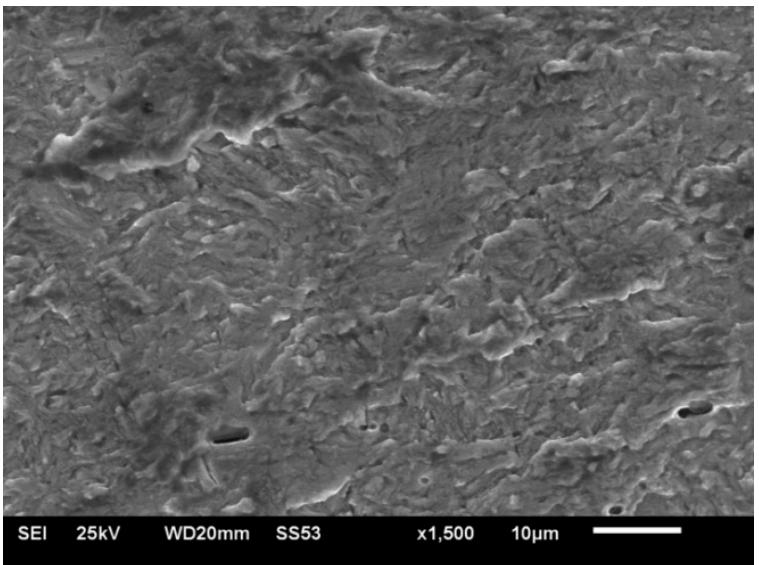

(a)

Figure 13. Cont. 


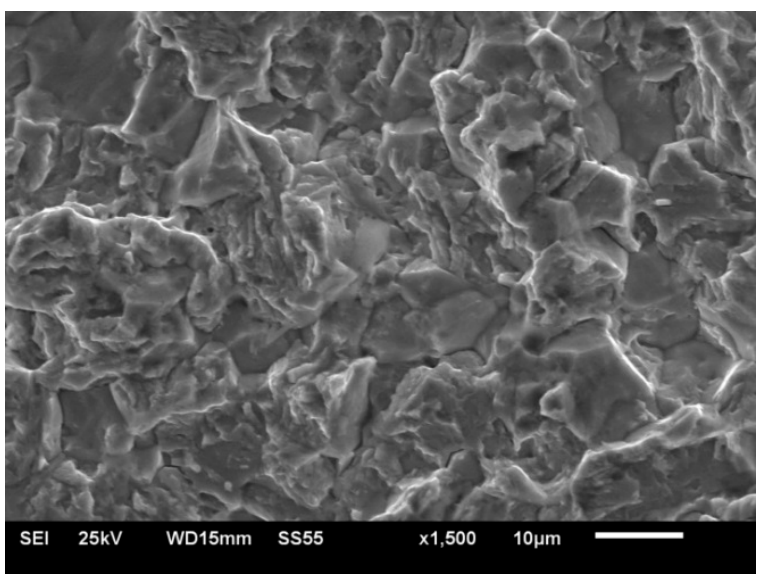

(b)

Figure 13. Typical Fatigue Fracture Surface Features Present in the Austempered 4140 Samples at low $\Delta \mathrm{K}$ Values. $(\Delta \mathrm{K}=19 \mathrm{MPa} \sqrt{ } \mathrm{m}$; crack growth direction was from top to bottom of photos). (a) Uncharged (No Hydrogen); (b) Hydrogen-Charged.

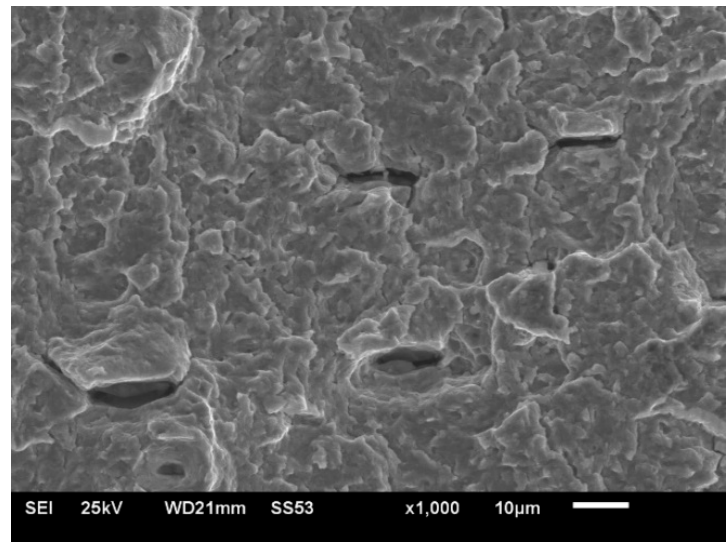

(a)

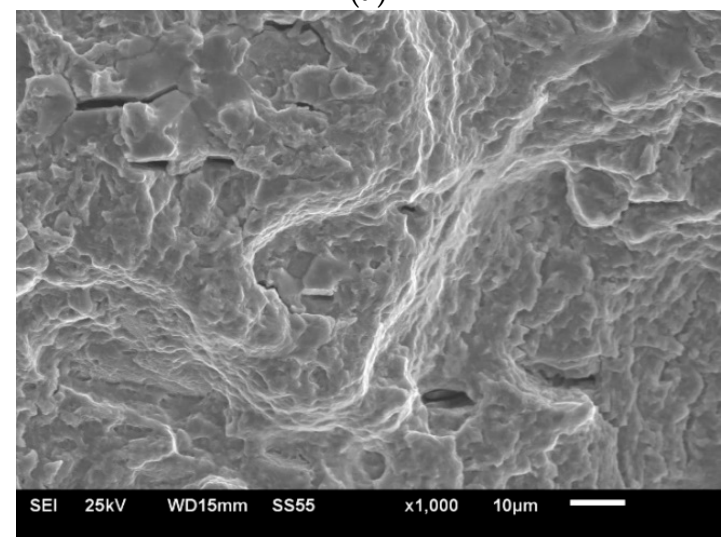

(b)

Figure 14. Typical Fatigue Fracture Surface Features Present in the Austempered 4140 Samples at high $\Delta \mathrm{K}$ Values. $(\Delta \mathrm{K}=50 \mathrm{MPa} \sqrt{ } \mathrm{m}$; crack growth direction was from top to bottom of photos). (a) Uncharged (No Hydrogen); (b) Hydrogen-Charged.

\section{Conclusions and Future Work}

To better understand the effect of hydrogen upon the mechanical properties and fatigue crack growth of austempered 4140 steel, the present research study was conducted. The study was conducted 
ex-situ to simulate the exposure of a 4140 alloy to hydrogen during manufacturing followed by usage in an ambient environment. From the data obtained in this study, the following conclusions can be drawn:

1. Austempering in the lower bainitic temperature range has significantly increased the mechanical properties and the fracture toughness of AISI 4140 steel as compared to the as-received (annealed) condition.

2. In the absence of any charged hydrogen, the austempered samples had a much lower average crack growth rate and higher fatigue threshold than the as-received (annealed) samples.

3. The presence of dissolved hydrogen increased the average crack growth rate in the austempered as well as in the as-received (annealed) samples.

4. There is a transition stress intensity factor value of approximately $40-50 \mathrm{MPa} \sqrt{ } \mathrm{m}$; below this value, the presence of dissolved hydrogen causes the crack growth rate to be higher in the austempered samples when compared to annealed samples.

5. In presence of dissolved hydrogen, above the transition stress intensity factor value, the crack growth rate was increasingly greater in the annealed specimens as compared to the austempered specimens.

6. When compared to the as-received (annealed) condition, austempering of 4140 steel appears to provide a processing route by which the strength, hardness, and fracture toughness of the material can be increased with little or no degradation in the ductility and fatigue crack growth behavior.

The results from this study also highlight the need for three future investigations. First, it is recommended that a study be conducted to better define the effect of austempering temperature on the fatigue crack growth resistance. This study would also need to more closely characterize crack closure effects and the effects of microstructural grains on the rate of crack propagation. Second, a study examining the effect of hydrogen concentration on the fatigue crack growth resistance in austempered 4140 should be conducted. This study should include hydrogen content measurements before and after the fatigue test in order to understand the effect of hydrogen diffusion, ingress, and outgassing during the testing process. Third, the study needs to be repeated for a quenched and tempered 4140 steel alloy that was exposed to hydrogen charging like that done in the current study. This will allow for an evaluation of the degree of commercial improvement yielded by austempering compared to the current commonly used heat treatment process.

Author Contributions: This research study was performed in fulfillment of a PhD Thesis by Varun Ramasagara Nagarajan. Susil K. Putatunda and Varun Ramasagara Nagarajan conceived and designed the experiments; James Boileau provided the material for this study; Varun Ramasagara Nagarajan performed the experiments; Varun Ramasagara Nagarajan, Susil K. Putatunda and James Boileau analyzed the data and wrote the paper.

Conflicts of Interest: The authors declare no conflict of interest.

\section{References}

1. Reed-Hill, R.E.; Abbaschian, R. Principles of Physical Metallurgy; PWS-Kent Publishing Company: Boston, MA, USA, 2010.

2. Mangoonan, P.L. The Principle of Material Selection in Engineering Design; Prentice Hall: Salle River, NJ, USA, 1999.

3. Putatunda, S.K. Fracture Toughness of a high carbon high silicon steel. Mater. Sci. Eng. A 2001, 297, 31-43. [CrossRef]

4. Putatunda, S.K.; Martis, C.; Boileau, J. Influence of austempering temperature on the mechanical properties of low carbon low alloy steel. Mater. Sci. Eng. A 2011, 528, 5053-5059. [CrossRef]

5. Putatunda, S.K.; Singar, A.V.; Tackett, R.; Lawes, G. Development of a high strength high toughness ausferritic steel. Mater. Sci. Eng. A 2009, 513-514, 329-339. [CrossRef]

6. ASTM E-399. Standard Test Method for determination of Plain Strain Fracture Toughness of Metallic Materials. In Annual Book of ASTM Standards; ASTM: Philadelphia, PA, USA, 2016; pp. 589-611. 
7. Paris, P.C.; Erdogan, F. A critical analysis of crack propagation laws. J. Basic Eng. 1963, 85, 528-534. [CrossRef]

8. Cwiek, J. Hydrogen degradation of high-strength steels. J. Achiev. Mater. Manuf. Eng. 2009, 37, $193-212$.

9. Lukacs, J. Fatigue crack propagation limit curves for different metallic and non-metallic materials. Mater. Sci. Forum 2003, 31, 414-415. [CrossRef]

10. Philips, T.V.; McCaffrey, T.J. Ultra High-Strength Steels. In Metals Handbook, 10th ed.; ASM: Geauga County, OH, USA, 1990; Volume 1, pp. 430-448.

11. Banerjee, K.; Chatterjee, U.K. Effect of microstructure on hydrogen embrittlement of weld-simulated HSLA-80 and HSLA-100 steels. Metall. Mater. Trans. A 2003, 34, 1297-1309. [CrossRef]

12. Jha, A.K.; Narayanan, P.R.; Sreekumar, K.; Mittal, M.C.; Ninan, K.N. Hydrogen embrittlement of 3.5Ni-1.5Cr-0.5Mo steel fastener. Eng. Fail. Anal. 2008, 15, 431-439. [CrossRef]

13. Lee, H.; Uhlig, H. Corrosion fatigue of type 4140 high strength steel. Metall. Mater. Trans. B 1972, 3, $2949-2957$. [CrossRef]

14. Murakami, Y.; Matusuoka, S. Effect of Hydrogen on fatigue crack growth of metals. Eng. Fract. Mech. 2010, 77, 1926-1940. [CrossRef]

15. Chuang, J.H.; Tsay, L.W.; Chen, C. Crack growth behaviour of heat-treated 4140 steel in air and gaseous hydrogen. Int. J. Fatigue 1998, 20, 531-536. [CrossRef]

16. Vergani, L.; Columbo, C.; Gobbi, G.; Bolzoni, F.M.; Fumagalli, G. Hydrogen effect on fatigue behavior of a quenched and tempered steel. Procedia Eng. 2014, 74, 468-471. [CrossRef]

17. Rao, P.P.; Putatunda, S.K. Comparative study of fracture toughness of austempered ductile irons with upper and lower ausferrite microstructures. Mater. Sci. Technol. 1998, 14, 1257-1265. [CrossRef]

18. Ramasagara Nagarajan, V.; Putatunda, S.K. Influence of dissolved hydrogen on the fatigue crack growth behavior of a low alloy (AISI 4140) steel. Int. J. Fatigue Special Issue Fatigue Damage Struct. Mater. IX 2014, 62, 236-248.

19. ASTM E-8. Standard Test Method for Tensile Testing of Materials. In Annual Book of ASTM Standards; ASTM: Philadelphia, PA, USA, 2016.

20. ASTM E-647. Standard Test Method for Fatigue Crack Growth Behavior of Materials. In Annual Book of ASTM Standards; ASTM: Philadelphia, PA, USA, 2016.

21. Karim, R.A. Cathodic hydrogen charging of high strength low alloy 4140 steel. Mater. Perform. 2006, 45, 58-63.

22. Hertzberg, R.W. Deformation of Fracture Mechanics of Engineering Materials, 3rd ed.; John Wiley \& Sons: Hoboken, NJ, USA, 1989.

23. Parvathavarthini, N.; Saroja, S.; Dayal, R.K.; Khatak, H.S. Studies on hydrogen permeability of $2.25 \% \mathrm{Cr}-1 \%$ Mo ferritic steel: Correlation with microstructure. J. Nucl. Mater. 2001, 288, 187-196.

24. Darken, L.S.; Smith, R.P. Behaviour of hydrogen in steel during and after immersion in acid. Corrosion 1949, 5, 1-16. [CrossRef]

25. Dong, C.F.; Li, X.G.; Liu, Z.Y.; Zhang, Y.R. Hydrogen-Induced cracking and healing behavior of X70 steel. J. Alloys Compd. 2009, 484, 966-972. [CrossRef]

26. Kim, C.D.; Longinow, A.W. Techniques for investigating hydrogen-Induced cracking of steels with high yield strength. Corrosion 1968, 24, 313-318. [CrossRef]

27. Rice, J.R. Fatigue Crack Propagation; ASTM STP 415; ASTM: Philadelphia, PA, USA, 1967; p. 247.

28. Nykyforchyn, H. Effect of hydrogen on the kinetics and mechanism of fatigue crack growth in structural steels. Mater. Sci. 1997, 33, 504-515. [CrossRef]

29. Tsay, L.W.; Liu, C.C.; Shieh, Y.H. Fatigue crack propagation in 2.25Cr-1.0Mo steel weldments in air and hydrogen. Mater. Sci. Eng. A 2001, 299, 16-26. [CrossRef]

(C) 2017 by the authors. Licensee MDPI, Basel, Switzerland. This article is an open access article distributed under the terms and conditions of the Creative Commons Attribution (CC BY) license (http:/ / creativecommons.org/licenses/by/4.0/). 